Document downloaded from:

http://hdl.handle.net/10251/104485

This paper must be cited as:

Momparler Perales, S.; Andrés Doménech, I.; Hernández Crespo, C.; Vallés-Morán, FJ.; Martín Monerris, M.; Escuder Bueno, I.; Andreu Álvarez, J. (2017). The role of monitoring sustainable drainage systems for promoting transition towards regenerative urban built environments: a case study in the Valencian region, Spain. Journal of Cleaner Production. 163:113-124. doi:10.1016/j.jclepro.2016.05.153

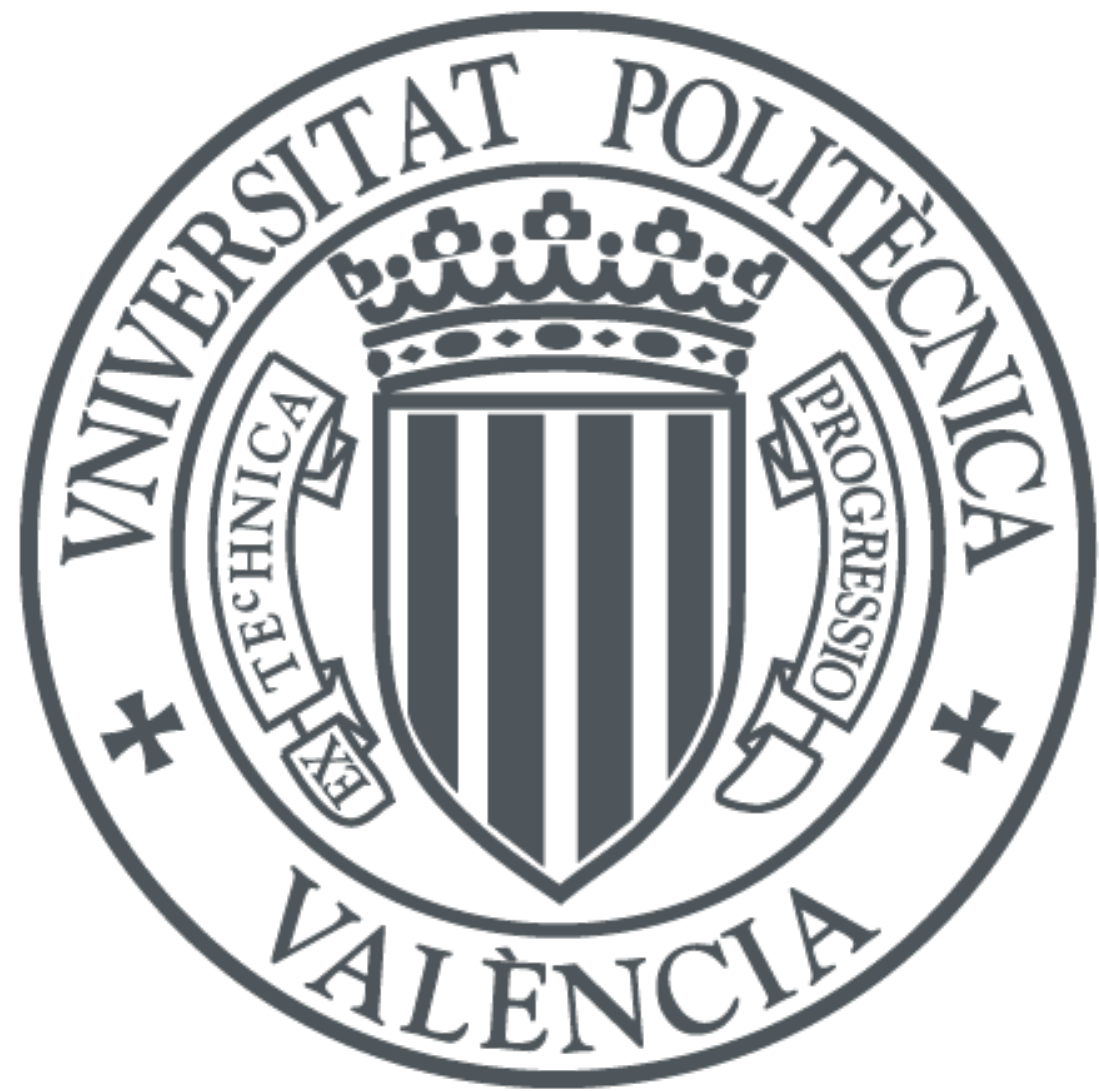

The final publication is available at

http://dx.doi.org/10.1016/j.jclepro.2016.05.153

Copyright Elsevier

Additional Information 


\title{
The role of monitoring sustainable drainage systems for promoting transition towards regenerative urban built environments: a case study in the Valencian region, Spain.
}

\author{
Sara Perales-Momparler ${ }^{a}$, Ignacio Andrés-Doménech ${ }^{b}$, Carmen Hernández- \\ Crespo $^{b}$, Francisco Vallés-Morán ${ }^{b}$, Miguel Martín ${ }^{b}$, Ignacio Escuder-Bueno ${ }^{b}$, \\ Joaquín Andreu ${ }^{\mathrm{b}}$ \\ ${ }^{a}$ Green Blue Management. Avda. del Puerto, 180-1B. 46023 Valencia. Spain. \\ ${ }^{b}$ Instituto Universitario de Investigación de Ingeniería del Agua y Medio Ambiente \\ (IIAMA). Universitat Politècnica de València. Cno. de Vera s/n. 46022. Valencia. Spain.
}

Corresponding author: Sara Perales-Momparler.

Green Blue Management. Avda. del Puerto, 180-1B. 46023 Valencia. Spain.

E-mail: sara.perales@greenbluemanagement.com

Mobile (1): (+34) 610611823

\section{Abstract}

Sustainable drainage systems are an alternative and holistic approach to conventional urban stormwater management that use and enhance natural processes to mimic pre-development hydrology, adding a number of wellrecognized, although not so often quantified benefits. However, transitions towards regenerative urban built environments that widely incorporate sustainable drainage systems are "per se" innovative journeys that encounter barriers which include the limited evidence on the performance of these systems which, in many countries, are still unknown to professionals and decision makers. A further important barrier is the frequently poor interaction among stakeholders; key items such as sustainable drainage systems provide collective benefits which also demand collective efforts. With the aim of overcoming such innovation-driven barriers, six showcase projects (including rain gardens acting as infiltration basins, swales and a green roof) to demonstrate the feasibility and suitability of sustainable drainage systems were developed and/or retrofitted in two cities of the Valencian region of Spain as a part of an European project, and 
their performance was monitored for a year. The data acquired, after being fully analyzed and presented to a group of key regional stakeholders, is proving to be a valuable promoter of the desired transition (for instance in influencing the support to SuDS in recent regional legislation). This paper presents detailed data on how these urban ecological drainage infrastructure elements reduce runoff (peak flows and volumes) and improve its quality, contributing to the goal of healthier and livable cities. The data show that the pilots have good hydraulic performance under a typical Mediterranean climate and also provided water quality benefits. Furthermore, it shows how engagement can contribute to smarter governance in the sense of smoothing the difficulties faced by innovation when being presented, understood, and endorsed by professionals and decisionmakers in the field of storm water management. Finally, activities undertaken in the demonstration sites monitored, show how they have been drivers of innovation and transition towards a new storm water paradigm in Spain, serving as a reference to other urban areas in the Mediterranean.

Keywords: Built environment; Mediterranean climate; Monitoring; Sustainable drainage systems; Transitions.

Abbreviations: $\mathbf{B O D}_{5}$, Five day biological oxygen demand; CFU, ColonyForming Unit; COD, Chemical oxygen demand; DO, Dissolved oxygen; SuDS, Sustainable Drainage Systems; TN, Total Nitrogen; TP, Total Phosphorus; TSS, Total Suspended Solids; VSS, Volatile Suspended Solids; WWTP, Waste water treatment plant.

\section{Highlights:}

- Sustainable drainage systems are innovative solutions in the Mediterranean.

- Pilot sites and monitoring are needed to show their feasibility in the Mediterranean.

- Engagement contributes to smarter governance in the field of stormwater management.

- Pilot sites are drivers of transition to a new stormwater paradigm in Spain. 


\section{Introduction}

Cities around the world face multiple challenges including expansion of paved areas, loss of vegetation cover and the effects of climate change. Conventional drainage systems are particularly impacted since normally their initial design was based on rapidly conveying stormwater runoff to receiving waters. All too often their capacity is now compromised by the increase of impermeable areas that produce larger amounts of runoff which is expected to increase further in many parts of the world due to climate change. This will also cause environmental damage not only because of changes to the flow regime but also to the increased loads of pollutants (Arnbjerg-Nielsen et al., 2013; Barbosa et al., 2012; Brown et al., 2009; Burns et al., 2012).

Sustainable Drainage Systems (SuDS) are an alternative and holistic approach to conventional stormwater management that use and enhance natural processes to mimic predevelopment hydrology. SuDS contribute to the mitigation of urban flooding and water pollution (Burns et al., 2012; Novotny et al., 2010) while saving energy in the urban water cycle and providing a non-conventional water resource, amenity, wildlife, carbon sequestration and storage, urban cooling, human-health and well-being (Charlesworth, 2010; Norton et al.; 2015). Hence, SuDS are part of the urban ecological infrastructure $(X u, 2012)$ that can be considered in broader greener plans $(\mathrm{Li}, 2005)$ as part of the transition towards regenerative urban built environments (du Plessis, 2012), a need highlighted by EU Ministers responsible for Urban Development (European Commission, 2010). However, such a journey encounters barriers including insufficient demonstration projects and a lack of interaction between stakeholders (Winz et al., 2014).

The complexity of such a transition process requires transition management (Jefferies and Duffy, 2011; van der Brugge and Rotmans, 2007), a governance approach that has the potential to overcome the inherent tension between the open-ended and uncertain process of sustainability transitions and the ambition for governing such a process through selective participatory activities of envisioning, negotiating, learning and experimenting (Frantzeskaki et al., 2012).

Sustainable transitions can be led by government (Loorbach and Rotmans, 2010), business (Loorbach et al., 2010), science, or civil society (Radywyl and Biggs, 2013; Woolthuis et al., 2013). In all cases it is crucial that, in order to enhance the quality of environmental decisions, stakeholder participation should emphasize empowerment, equity, trust and learning (Pahl-Wostl et al., 2008; Reed 2008; Smith and Raven, 2012). This requires the involvement of governmental and non-governmental multidisciplinary professionals (Jim, 2004; Potter et al., 2011), ever more important in a changing climate where the design and optimization of urban drainage infrastructure needs to be co-optimized with other objectives to keep cities habitable into the future (Arnbjerg-Nielsen et al., 2013). 
The lack of available demonstration projects with appropriate monitoring is an important barrier (Brown and Farrely, 2009; Hunt and Rogers, 2005) that

challenges the implementation of novel systems. Indeed, both government and industry require clear evidence about their benefits and costs, customized for the region of study, to be willing to invest. Furthermore, there is evidence that demonstration sites have facilitated the development of mature understanding of innovative approaches such as integrated urban water management (Mitchell, 2006). Demo sites help in the identification of opportunities and substantial cost savings for local communities that are not apparent when separate strategies are

Although SuDS have been implemented in many parts of the globe (Novotny et al., 2010), experience is limited in the Mediterranean region (Castro-Fresno et al., 2013; Charlesworth et al., 2013; Chouli et al., 2007) in particular characterizing the response of SuDS in the region, with its long dry periods and torrential rain (Millán et al., 2013; Perales-Momparler et al., 2014; Terzakis et al., 2008). Hence, there is a need for 'learning by doing' experiments which can demonstrate the effectiveness of this new approach (Barbosa et al., 2012; Binney et al., 2010; Casal-Campos et al., 2012; Lamera et al., 2014; Tukker and Butter, 2007) since, according to Nevens et al. (2013), experiments can be major triggers for the take-off and acceleration of transitions (Van der Brugge and Rotmans, 2007).

As Willke (2007) affirms, the creation of new knowledge becomes paramount for smart forms of governance. However, new knowledge has to fight for acceptance against conservatism and a host of difficulties, because knowledge is part of, and embedded in, social relationships. More specifically, new knowledge in civil engineering does not move easily into practice when professionals do not have codes, guidelines and/or evidence of proper performance that they can reference to justify due diligence in design and construction.

This paper aims to enhance smart governance in this context by providing information about the successful implementation and monitoring of SuDS showcase sites in Mediterranean Spain. These showcase sites are promoting the transition towards regenerative urban built environments in the region in the context of enhanced and intelligent governance (Halpin and Escuder, 2015; Perales-Momparler et al., 2015). In addition, this article expands the current list of references for improved urban ecological infrastructure, particularly scarce in the Mediterranean area and certainly improvable in terms of quantification of the benefits of SuDS, by demonstrating what success can look like (Binney et al., 2010). 


\section{Description of Showcase Sites}

With the aim of overcoming barriers to innovation, six showcase sites (Fig. 1) demonstrating the feasibility and suitability of SuDS were developed in two cities in the Valencian region in Spain within the framework of the AQUAVAL EU project (Life08ENV/E/000099, www.aquavalproject.eu). The sewer system (mainly combined) in both urban areas suffered from lack of capacity during intense, frequent rainfall events causing pluvial flooding and the discharge of combined sewage into the receiving water courses.

Table 1 presents a summary of the roadside swales, detention-infiltration basin and green roof built in Xàtiva (29 400 inhabitants) and the several detentioninfiltration basins and harvesting tank retrofitted in Benaguasil (11300 inhabitants). All six sites are easily accessible for viewing by the public and include notice boards for information and educational purposes enhancing their value as showcase sites. More detailed descriptions and explanations can be found in Perales-Momparler et al. (2013 and 2014), and Casal-Campos et al. (2012) which also describes the decision-support process used for sites and SuDS options selection.

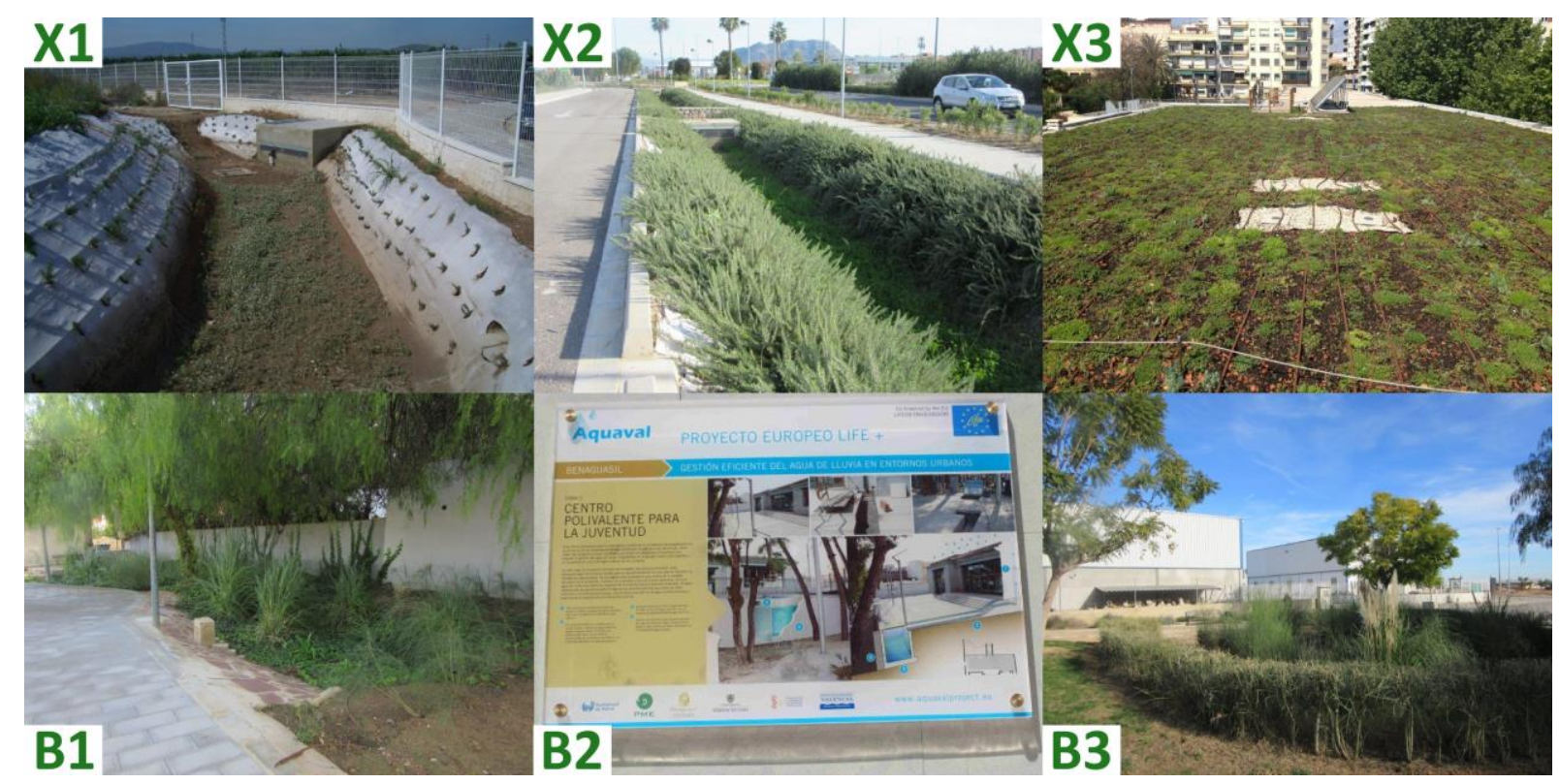

Fig. 1. Showcase sites after SuDS development/retrofitting in Xàtiva (upper row) and Benaguasil (lower row). 
Table 1. Summary description of showcase Sites.

\begin{tabular}{|c|c|c|c|c|c|}
\hline $\begin{array}{l}\text { Site } \\
\text { Code: location }\end{array}$ & $\begin{array}{l}\text { Type of } \\
\text { SuDs }\end{array}$ & Main function & $\begin{array}{l}\text { Criteria for } \\
\text { site selection }\end{array}$ & $\begin{array}{l}\text { Area of works } \\
\text { / Drained area }\end{array}$ & $\begin{array}{l}\text { Construction } \\
\text { cost* }\end{array}$ \\
\hline $\begin{array}{l}\text { X1: Xàtiva } \\
\text { Sports City }\end{array}$ & $\begin{array}{l}\text { Infiltration } \\
\text { basin }\end{array}$ & Runoff reduction & $\begin{array}{l}\text { Drainage } \\
\text { required and } \\
\text { public space } \\
\text { available }\end{array}$ & $\begin{array}{l}415 \mathrm{~m}^{2} / \\
17350 \mathrm{~m}^{2} \\
\text { (Works include } \\
\text { a } 75 \mathrm{~m} \text { long, } \\
1.1 \text { wide base } \\
\text { swale, linked to } \\
50 \mathrm{~m}^{2} \text { basin) }\end{array}$ & $\begin{array}{l}565 € / \mathrm{m}^{3} \\
\text { retention } \\
\text { volume }\end{array}$ \\
\hline $\begin{array}{l}\text { X2: Xàtiva } \\
\text { North Ring } \\
\text { Road }\end{array}$ & $\begin{array}{l}\text { Roadside } \\
\text { swale } \\
\text { functioning } \\
\text { as a } \\
\text { longitudinal } \\
\text { infiltration } \\
\text { basin }\end{array}$ & $\begin{array}{l}\text { Runoff reduction } \\
\text { and quality } \\
\text { improvement }\end{array}$ & $\begin{array}{l}\text { Drainage } \\
\text { required and } \\
\text { public space } \\
\text { available }\end{array}$ & $\begin{array}{l}3700 \mathrm{~m}^{2} / \\
12560 \mathrm{~m}^{2} \\
\text { (1.7 m wide } \\
\text { base) }\end{array}$ & $175 € / \mathrm{m}$ \\
\hline $\begin{array}{l}\text { X3:Gonzalbes } \\
\text { Vera public } \\
\text { school in Xàtiva }\end{array}$ & Green Roof & $\begin{array}{l}\text { Runoff reduction } \\
\text { and building } \\
\text { insulation }\end{array}$ & $\begin{array}{l}\text { Educational } \\
\text { opportunity; } \\
\text { comparison on } \\
\text { runoff } \\
\text { discharged from } \\
\text { the green roof } \\
\text { and from the } \\
\text { conventional } \\
\text { roof }\end{array}$ & $\begin{array}{l}475 \mathrm{~m}^{2} / \\
475 \mathrm{~m}^{2} \\
\text { (Monitored } \\
\text { area: } 218 \mathrm{~m}^{2} \text { ) }\end{array}$ & $161 € / \mathrm{m}^{2}$ \\
\hline $\begin{array}{l}\text { B1: Costa } \\
\text { Ermita park in } \\
\text { Benaguasil }\end{array}$ & $\begin{array}{l}\text { Detention- } \\
\text { infiltration } \\
\text { basins }\end{array}$ & $\begin{array}{l}\text { Sediments } \\
\text { detention and } \\
\text { runoff reduction }\end{array}$ & $\begin{array}{l}\text { Public space } \\
\text { available in an } \\
\text { elevated town } \\
\text { area }\end{array}$ & $\begin{array}{l}600 \mathrm{~m}^{2} / \\
9330 \mathrm{~m}^{2}\end{array}$ & $\begin{array}{l}880 € / \mathrm{m}^{3} \\
\text { retention } \\
\text { volume }\end{array}$ \\
\hline $\begin{array}{l}\text { B2: Benaguasil } \\
\text { Youth Center }\end{array}$ & $\begin{array}{l}\text { Underground } \\
\text {-concrete } \\
\text { rainwater } \\
\text { harvesting } \\
\text { tank }\end{array}$ & $\begin{array}{l}\text { Rainwater } \\
\text { harvesting }\end{array}$ & $\begin{array}{l}\text { Educational } \\
\text { opportunity and } \\
\text { revival of a lost } \\
\text { ancient practice }\end{array}$ & $25 \mathrm{~m}^{2} / 100 \mathrm{~m}^{2}$ & $\begin{array}{l}1584 € / \mathrm{m}^{3} \\
\text { retention } \\
\text { volume }\end{array}$ \\
\hline $\begin{array}{l}\text { B3: Les Eres } \\
\text { industrial park } \\
\text { in Benaguasil }\end{array}$ & $\begin{array}{l}\text { Infiltration } \\
\text { basin }\end{array}$ & Runoff reduction & $\begin{array}{l}\text { Showcase for } \\
\text { future } \\
\text { expansion of } \\
\text { industrial area } \\
\text { and public space } \\
\text { available }\end{array}$ & $\begin{array}{l}410 \mathrm{~m}^{2} / \\
1190 \mathrm{~m}^{2}\end{array}$ & $\begin{array}{l}290 € / \mathrm{m}^{3} \\
\text { retention } \\
\text { volume }\end{array}$ \\
\hline
\end{tabular}

* Final cost including works to redirect runoff, infrastructure required for monitoring tasks

3 (monitoring equipment not included) and notice boards.

4

5 2.1. Monitoring of water quantity variables

6 Full rainfall and flow monitoring programmes were undertaken in each site to 7 investigate their hydraulic response and performance (Perales-Momparler et al., 8 2014). 
1 In Xàtiva, rainfall data was collected by the Spanish Meteorological Agency 2 (AEMET). In Benaguasil, a Detectronic rainfall gauge ( $0.2 \mathrm{~mm}$ accuracy) with a 3 Bühler Montec datalogger was installed.

4 The purpose of the monitoring was to quantify the rate and volume of overflow 5 from each structure into the downstream system together with the volume of 6 water detained or harvested. Different equipment was used depending on the 7 SuDS type and where the device was installed: V-notch weirs $\left(90^{\circ}\right)$ with a level 8 probe, ultrasonic flow meters and tipping bucket flow gauges. All the details 9 regarding the equipment installed in Xàtiva can be found in Perales-Momparler et 10 al. (2014). The equipment used in Benaguasil is the same as in Xàtiva. Table 2

Table 2. Monitoring of quantity variables (adapted and completed from PeralesMomparler et al., 2014).

\begin{tabular}{|c|c|c|c|c|}
\hline Site & Device & Monitored variable & $\begin{array}{l}\text { Monitoring start } \\
\text { date }\end{array}$ & $\begin{array}{l}\text { Monitoring end } \\
\text { date }\end{array}$ \\
\hline $\mathrm{X} 1$ & $\begin{array}{l}\text { V-notch weir }+ \text { level } \\
\text { probe }\end{array}$ & Discharge from the basin & $27 / 09 / 2012$ & $30 / 09 / 2013$ \\
\hline $\mathrm{X} 2$ & $\begin{array}{l}\text { V-notch weir }+ \text { level } \\
\text { probe }\end{array}$ & Discharge from the swale & $19 / 09 / 2012$ & $30 / 09 / 2013$ \\
\hline $\mathrm{X3}$ & $\begin{array}{l}\text { Tipping bucket flow } \\
\text { meters }\end{array}$ & $\begin{array}{l}\text { Runoff from the green } \\
\text { roof and from the } \\
\text { conventional roof }\end{array}$ & $18 / 10 / 2012$ & $30 / 09 / 2013$ \\
\hline B1 & $\begin{array}{l}\text { V-notch weir }+ \text { level } \\
\text { probe }\end{array}$ & Discharge from the basin & $06 / 11 / 2012$ & $30 / 09 / 2013$ \\
\hline B2 & Level probe & $\begin{array}{l}\text { Volume stored in the } \\
\text { tank }\end{array}$ & $30 / 11 / 2012$ & $30 / 09 / 2013$ \\
\hline B3 & Ultrasonic flow meter & Discharge from the basin & $06 / 11 / 2012$ & $30 / 09 / 2013$ \\
\hline
\end{tabular}

\subsection{Monitoring of water quality variables}

In terms of water quality monitoring, ten and six water sampling points were used in Xàtiva and Benaguasil SuDS respectively. Details of sampling points can be found in Table 3 and the sampling procedure is described in PeralesMomparler et al. (2014).

Water was collected using 2 I plastic bottles with one bottle per sampling point per event. Since the bottles filled at the beginning of each rainfall event, the water quality observed corresponded to the first wash off. The bottles at the outlets (points X13, X23, B13 and B22) were filled only if there was discharge. COD, TN and TP were analyzed using a Spectroquant ${ }^{\circledR}$ analysis system by Merck. $\mathrm{BOD}_{5}$ was measured using OxiTop ${ }^{\circledR}$. TSS and VSS were determined according to the Standard Methods for examination of water and wastewater (APHA, 1991). 
1 Water temperature, $\mathrm{pH}$, conductivity, and DO were measured with WTW ${ }^{\circledR}$ probes

2 in situ.

3 Regarding statistical analyses, descriptive statistics were calculated and results 4 are displayed by boxplots. Correlation coefficients ( $r_{\text {Pearson }}$ ) between water quality 5 variables are also calculated. The influence of meteorological variables 6 (antecedent dry period, rainfall intensity) was analyzed using a multivariate 7 analysis (linear regression with stepwise selection method). The influence of 8 contaminants origin was evaluated by comparing the results from different 9 sampling points using Kruskal-Wallis test (significance level, $p<0.05$ ). The statistical analyses were performed using SPSS 16.0 software (SPSS ${ }^{\circledR}$ software).

Table 3. Description of monitored sites and sampling points (X: Xàtiva; B: Benaguasil;

Id.: identification code; $N$ : number of monitored events).

\begin{tabular}{|l|l|l|l|}
\hline \multicolumn{1}{|c|}{ Site } & \multicolumn{1}{|c|}{ Description } & Id. & \multicolumn{1}{|c|}{$\mathrm{N}$} \\
\hline X1 & Inflow 1 from recreational area & X11 & 11 \\
\cline { 2 - 4 } & Inflow 2 from road with traffic & X12 & 11 \\
\cline { 2 - 4 } & Outflow to sewer system & X13 & 7 \\
\hline X2 & Inflow 1, from road without traffic & X21 & 8 \\
\cline { 2 - 4 } & Inflow 2, from road with traffic & X22 & 11 \\
\cline { 2 - 4 } & Outflow to sewer system & X23 & 4 \\
\hline X3 & Outflow from green roof & X31 & 9 \\
\cline { 2 - 4 } & Outflow from non-vegetated roof & X32 & 9 \\
\cline { 2 - 4 } & Atmospheric deposition & X33 & 5 \\
\cline { 2 - 4 } & Harvesting tank & X34 & 7 \\
\hline B1 & Inflow from road with traffic & B11 & 8 \\
\cline { 2 - 5 } & Outflow to sewer system & B13 & 0 \\
\hline B2 & Atmospheric deposition & B21 & 4 \\
\cline { 2 - 4 } & Harvesting tank & B22 & 5 \\
\hline \multirow{2}{*}{ B3 } & Inflow from industrial warehouse & 6 \\
\cline { 2 - 4 } & Outflow to sewer system & B32 & 1 \\
\hline
\end{tabular}

14

15

\section{Monitoring results and discussion}

Results of the monitoring period are presented herein. First, the rainfall pattern is analyzed provided its importance on hydraulic and water quality variables. Then, ability of SuDS to smooth the hydraulic response of the system and to improve the runoff water quality is discussed.

\subsection{Rainfall patterns during the monitored period}

During the monitoring period, 17 events were recorded in Xàtiva (Table 4) and 19 in Benaguasil (Table 5) which corresponds to the dry period in the Mediterranean region. In Valencia, the average number of events per year for the period 1990-2006 is 27.3 (Andrés-Doménech et al., 2010). The annual average rainfall is $690 \mathrm{~mm}$ in Xàtiva and 430 in Benaguasil. During the year 
1 monitored, $618 \mathrm{~mm}$ were recorded in Xàtiva $(-10 \%)$ and $373 \mathrm{~mm}$ in Benaguasil $2 \quad(-13 \%)$. The heaviest events occurred at the end of the summer and in autumn 3 (event 1 at both locations and event 19 in Benaguasil) even though there were 4 also typical spring showers recorded during the year monitored (events 13 and 515 in Xàtiva and event 14 in Benaguasil). Tables 4 and 5 summarize the key 6 variables of each event recorded: start and end dates, previous inter-event dry 7 period, duration, rainfall depth and maximum 10-min intensity.

8

Table 4. Rainfall events recorded in Xàtiva.

\begin{tabular}{|c|c|c|c|c|c|c|}
\hline Event & Start date & End date & $\begin{array}{l}\text { Previous } \\
\text { inter-event } \\
\text { dry period } \\
\text { (days) }\end{array}$ & $\begin{array}{c}\text { Event } \\
\text { duration } \\
\text { (h) }\end{array}$ & $\begin{array}{c}\text { Event } \\
\text { rainfall } \\
\text { depth }(\mathbf{m m})\end{array}$ & $\begin{array}{c}\text { Maximum } \\
10-\mathrm{min} \\
\text { intensity } \\
\left(\mathrm{mm} \mathrm{h}^{-1}\right)\end{array}$ \\
\hline 1 & $\begin{array}{c}27 / 09 / 2012 \\
15: 30\end{array}$ & $\begin{array}{c}30 / 09 / 2012 \\
10: 00 \\
\end{array}$ & 28.50 & 66 & 92.0 & 73.2 \\
\hline 2 & $\begin{array}{c}12 / 10 / 2012 \\
17: 50 \\
\end{array}$ & $\begin{array}{c}13 / 10 / 2012 \\
00: 40 \\
\end{array}$ & 12.3 & 7 & 35.4 & 48.0 \\
\hline 3 & $\begin{array}{c}19 / 10 / 2012 \\
21: 50\end{array}$ & $\begin{array}{c}21 / 10 / 2012 \\
12: 30\end{array}$ & 6.9 & 39 & 23.8 & 9.6 \\
\hline 4 & $\begin{array}{c}25 / 10 / 2012 \\
05: 40\end{array}$ & $\begin{array}{c}25 / 10 / 2012 \\
19: 20\end{array}$ & 3.7 & 14 & 5.6 & 6.0 \\
\hline 5 & $\begin{array}{c}30 / 10 / 2012 \\
13: 20 \\
\end{array}$ & $\begin{array}{c}31 / 10 / 2012 \\
06: 10 \\
\end{array}$ & 4.8 & 17 & 5.4 & 3.6 \\
\hline 6 & $\begin{array}{c}09 / 11 / 2012 \\
06: 20\end{array}$ & $\begin{array}{c}15 / 11 / 2012 \\
17: 40\end{array}$ & 9.0 & 155 & 202.8 & 42.0 \\
\hline 7 & $\begin{array}{c}17 / 11 / 2012 \\
21: 30\end{array}$ & $\begin{array}{c}19 / 11 / 2012 \\
04: 00\end{array}$ & 2.2 & 30 & 8.0 & 6.0 \\
\hline 8 & $\begin{array}{c}26 / 11 / 2012 \\
06: 30\end{array}$ & $\begin{array}{c}27 / 11 / 2012 \\
15: 20\end{array}$ & 7.1 & 33 & 9.6 & 6.0 \\
\hline 9 & $\begin{array}{c}25 / 12 / 2012 \\
23: 10 \\
\end{array}$ & $\begin{array}{c}26 / 12 / 2012 \\
06: 40 \\
\end{array}$ & 28.3 & 8 & 4.6 & 2.4 \\
\hline 10 & $\begin{array}{c}19 / 02 / 2013 \\
12: 40\end{array}$ & $\begin{array}{c}20 / 02 / 2013 \\
03: 40\end{array}$ & 55.3 & 15 & 5.6 & 3.6 \\
\hline 11 & $\begin{array}{c}27 / 02 / 2013 \\
11: 10\end{array}$ & $\begin{array}{c}01 / 03 / 2013 \\
18: 40\end{array}$ & 7.3 & 56 & 132.4 & 21.6 \\
\hline 12 & $\begin{array}{c}04 / 03 / 2013 \\
03: 30\end{array}$ & $\begin{array}{c}05 / 03 / 2013 \\
22: 10\end{array}$ & 2.4 & 43 & 16.8 & 4.8 \\
\hline 13 & $\begin{array}{c}05 / 04 / 2013 \\
12: 50\end{array}$ & $\begin{array}{c}05 / 04 / 2013 \\
20: 40\end{array}$ & 30.6 & 8 & 29.2 & 43.2 \\
\hline 14 & $\begin{array}{c}25 / 04 / 2013 \\
02: 20\end{array}$ & $\begin{array}{c}29 / 04 / 2013 \\
02: 20\end{array}$ & 19.2 & 96 & 88.3 & 10.8 \\
\hline 15 & $\begin{array}{c}14 / 05 / 2013 \\
09: 30 \\
\end{array}$ & $\begin{array}{c}16 / 05 / 2013 \\
03: 20 \\
\end{array}$ & 15.3 & 42 & 15.4 & 42.0 \\
\hline 16 & $\begin{array}{c}27 / 05 / 2013 \\
15: 00\end{array}$ & $\begin{array}{c}30 / 05 / 2013 \\
08: 00\end{array}$ & 11.5 & 65 & 4.8 & - \\
\hline 17 & $\begin{array}{c}27 / 08 / 2013 \\
17: 00\end{array}$ & $\begin{array}{c}31 / 08 / 2013 \\
17: 00\end{array}$ & 89.4 & 96 & 30.6 & - \\
\hline
\end{tabular}


Table 5. Rainfall events recorded in Benaguasil.

\begin{tabular}{|c|c|c|c|c|c|c|}
\hline Event & Start date & End date & $\begin{array}{l}\text { Previous } \\
\text { inter-event } \\
\text { dry (days) }\end{array}$ & $\begin{array}{c}\text { Event } \\
\text { duration } \\
\text { (h) }\end{array}$ & $\begin{array}{c}\text { Event } \\
\text { rainfall } \\
\text { depth }(\mathbf{m m})\end{array}$ & $\begin{array}{c}\text { Maximum } \\
10-m i n \\
\text { intensity } \\
\left(\mathrm{mm} \mathrm{h}^{-1}\right)\end{array}$ \\
\hline 1 & $\begin{array}{c}27 / 09 / 2012 \\
06: 00\end{array}$ & $\begin{array}{c}30 / 09 / 2012 \\
11: 20\end{array}$ & - & 77 & 72.0 & 62.4 \\
\hline 2 & $\begin{array}{c}12 / 10 / 2012 \\
15: 20\end{array}$ & $\begin{array}{c}14 / 10 / 2012 \\
23: 50\end{array}$ & 12.2 & 56 & 7.4 & 6.0 \\
\hline 3 & $\begin{array}{c}19 / 10 / 2012 \\
22: 40\end{array}$ & $\begin{array}{c}21 / 10 / 2012 \\
04: 30\end{array}$ & 5.0 & 30 & 55.2 & 58.8 \\
\hline 4 & $\begin{array}{c}25 / 10 / 2012 \\
05: 50\end{array}$ & $\begin{array}{c}26 / 10 / 2012 \\
06: 30\end{array}$ & 4.1 & 25 & 5.4 & 2.4 \\
\hline 5 & $\begin{array}{c}30 / 10 / 2012 \\
14: 40\end{array}$ & $\begin{array}{c}30 / 10 / 2012 \\
22: 20\end{array}$ & 4.3 & 8 & 4.0 & 3.6 \\
\hline 6 & $\begin{array}{c}09 / 11 / 2012 \\
03: 10\end{array}$ & $\begin{array}{c}09 / 11 / 2012 \\
22: 30\end{array}$ & 9.2 & 19 & 6.0 & 14.4 \\
\hline 7 & $\begin{array}{c}11 / 11 / 2012 \\
14: 00\end{array}$ & $\begin{array}{c}11 / 11 / 2012 \\
22: 50\end{array}$ & 1.6 & 9 & 4.2 & 3.6 \\
\hline 8 & $\begin{array}{c}13 / 11 / 2012 \\
13: 20\end{array}$ & $\begin{array}{c}13 / 11 / 2012 \\
21: 10\end{array}$ & 1.6 & 8 & 4.4 & 9.6 \\
\hline 9 & $\begin{array}{c}17 / 11 / 2012 \\
08: 10\end{array}$ & $\begin{array}{c}18 / 11 / 2012 \\
16: 30\end{array}$ & 3.5 & 32 & 10.6 & 12.0 \\
\hline 10 & $\begin{array}{c}24 / 01 / 2013 \\
09: 50\end{array}$ & $\begin{array}{c}24 / 01 / 2013 \\
13: 30\end{array}$ & 66.7 & 4 & 1.8 & 8.4 \\
\hline 11 & $\begin{array}{c}28 / 02 / 2013 \\
00: 40\end{array}$ & $\begin{array}{c}01 / 03 / 2013 \\
12: 20\end{array}$ & 34.5 & 36 & 13.0 & 4.8 \\
\hline 12 & $\begin{array}{c}04 / 03 / 2013 \\
18: 10\end{array}$ & $\begin{array}{c}05 / 03 / 2013 \\
22: 22\end{array}$ & 3.2 & 28 & 30.2 & 6.0 \\
\hline 13 & $\begin{array}{c}05 / 04 / 2013 \\
14: 30\end{array}$ & $\begin{array}{c}05 / 04 / 2013 \\
18: 20\end{array}$ & 30.7 & 4 & 11.0 & 10.8 \\
\hline 14 & $\begin{array}{c}25 / 04 / 2013 \\
05: 10\end{array}$ & $\begin{array}{c}30 / 04 / 2013 \\
23: 50\end{array}$ & 19.5 & 139 & 78.2 & 39.6 \\
\hline 15 & $\begin{array}{c}14 / 05 / 2013 \\
05: 00\end{array}$ & $\begin{array}{c}15 / 05 / 2013 \\
15: 00 \\
\end{array}$ & 13.2 & 34 & 8.2 & 4.8 \\
\hline 16 & $\begin{array}{c}30 / 05 / 2013 \\
01: 40\end{array}$ & $\begin{array}{c}30 / 05 / 2013 \\
03: 40\end{array}$ & 14.4 & 2 & 3.4 & 2.4 \\
\hline 17 & $\begin{array}{c}21 / 06 / 2013 \\
19: 40\end{array}$ & $\begin{array}{c}21 / 06 / 2013 \\
21: 20\end{array}$ & 22.7 & 2 & 4.8 & 10.8 \\
\hline 18 & $\begin{array}{c}09 / 07 / 2013 \\
19: 40\end{array}$ & $\begin{array}{c}10 / 07 / 2013 \\
23: 50\end{array}$ & 17.9 & 28 & 8.0 & 19.2 \\
\hline 19 & $\begin{array}{c}26 / 08 / 2013 \\
01: 30\end{array}$ & $\begin{array}{c}30 / 08 / 2013 \\
07: 10\end{array}$ & 46.1 & 102 & 45.2 & 48.0 \\
\hline
\end{tabular}

\subsection{Hydraulic performance}

4 The hydraulic performance of each pilot site was analyzed against rainfall events 5 of different magnitude. In Xàtiva, sites $X 1$ and $X 2$ were able to cope with all the 6 runoff generated in the events which had a total depth of $25 \mathrm{~mm}$ or less. In 7 events of greater magnitude, the volume draining to the sewer network was 8 significantly reduced with volumetric efficiencies always greater than $65 \%$ (Table 9 6). The antecedent dry period also affected the hydraulic performance of the site. 10 Events 2, 13 and 17 had very similar rainfall depths: $35.4,29.2$ and $30.6 \mathrm{~mm}$ respectively. Nevertheless, all events except 17 produced overflow where the antecedent dry period was almost 3 months, whereas for events 2 and 13 there were only 12 and 31 previous dry days respectively. 
Table 6. Hydraulic efficiency of pilots X1 and $\times 2$.

\begin{tabular}{|c|c|c|c|c|c|}
\hline \multirow{2}{*}{ Event } & \multirow{2}{*}{$\begin{array}{l}\text { Event rainfall } \\
\text { depth }(\mathrm{mm})\end{array}$} & \multicolumn{2}{|c|}{ X1 - Infiltration basin } & \multicolumn{2}{|c|}{ X2 - Roadside swale } \\
\hline & & $\begin{array}{c}\text { Spilled volume } \\
(\mathrm{mm})\end{array}$ & $\begin{array}{c}\text { Volumetric } \\
\text { efficiency }(\%)\end{array}$ & $\begin{array}{c}\text { Spilled volume } \\
(\mathrm{mm})\end{array}$ & $\begin{array}{c}\text { Volumetric } \\
\text { efficiency }(\%)\end{array}$ \\
\hline 1 & 92.0 & 15.1 & 84 & 16.4 & 82 \\
\hline 2 & 35.4 & 4.2 & 88 & 4.8 & 86 \\
\hline 3 & 23.8 & 0 & 100 & 0 & 100 \\
\hline 4 & 5.6 & 0 & 100 & 0 & 100 \\
\hline 5 & 5.4 & 0 & 100 & 0 & 100 \\
\hline 6 & 202.8 & 33.4 & 84 & 18.8 & 91 \\
\hline 7 & 8.0 & 0 & 100 & 2.6 & 68 \\
\hline 8 & 9.6 & 0 & 100 & 0 & 100 \\
\hline 9 & 4.6 & 0 & 100 & 0 & 100 \\
\hline 10 & 5.6 & 0 & 100 & 0 & 100 \\
\hline 11 & 132.4 & $\mathrm{n} / \mathrm{a}$ & $\mathrm{n} / \mathrm{a}$ & 6.8 & 95 \\
\hline 12 & 16.8 & 0 & 100 & 0 & 100 \\
\hline 13 & 29.2 & 1.5 & 95 & 0.2 & 99 \\
\hline 14 & 88.3 & 32.0 & 64 & 0.9 & 99 \\
\hline 15 & 15.4 & 0 & 100 & 0 & 100 \\
\hline 16 & 4.8 & $\mathrm{n} / \mathrm{a}$ & $\mathrm{n} / \mathrm{a}$ & $\mathrm{n} / \mathrm{a}$ & $\mathrm{n} / \mathrm{a}$ \\
\hline 17 & 30.6 & 0 & 100 & 0 & 100 \\
\hline
\end{tabular}

2

Table 7. Hydraulic efficiency in site $X 3$. Comparison between the green roof and the conventional roof.

\begin{tabular}{|c|c|c|c|c|c|}
\hline \multirow{2}{*}{ Event } & \multirow{2}{*}{$\begin{array}{c}\text { Event rainfall } \\
\text { depth } \mathbf{( m m )}\end{array}$} & \multicolumn{2}{|c|}{ X3 - Conventional roof } & \multicolumn{2}{c|}{ X3 - Green roof } \\
\cline { 3 - 6 } & & $\begin{array}{c}\text { Spilled volume } \\
(\mathbf{m m})\end{array}$ & $\begin{array}{c}\text { Volumetric } \\
\text { efficiency (\%) }\end{array}$ & $\begin{array}{c}\text { Spilled volume } \\
(\mathbf{m m})\end{array}$ & $\begin{array}{c}\text { Volumetric } \\
\text { efficiency (\%) }\end{array}$ \\
\hline 8 & 9.6 & 5.3 & 45 & 4.5 & 53 \\
\hline 9 & 4.6 & 3.2 & 30 & 1.2 & 74 \\
\hline 10 & 5.6 & 2.6 & 54 & 0.0 & 100 \\
\hline 11 & 132.4 & $\mathrm{n} / \mathrm{a}$ & $\mathrm{n} / \mathrm{a}$ & $\mathrm{n} / \mathrm{a}$ & $\mathrm{n} / \mathrm{a}$ \\
\hline 12 & 16.8 & 13.5 & 20 & $\mathrm{n} / \mathrm{a}$ & $\mathrm{n} / \mathrm{a}$ \\
\hline 13 & 29.2 & 21.6 & 26 & 4.0 & 86 \\
\hline 14 & 88.3 & 60.7 & 31 & 17.7 & 80 \\
\hline 15 & 15.4 & $\mathrm{n} / \mathrm{a}$ & $\mathrm{n} / \mathrm{a}$ & $\mathrm{n} / \mathrm{a}$ & $\mathrm{n} / \mathrm{a}$ \\
\hline 16 & 4.8 & $\mathrm{n} / \mathrm{a}$ & $\mathrm{n} / \mathrm{a}$ & $\mathrm{n} / \mathrm{a}$ & $\mathrm{n} / \mathrm{a}$ \\
\hline 17 & 30.6 & 28.2 & 8 & 13.9 & 55 \\
\hline
\end{tabular}

The runoff produced from the green and conventional roofs at site X3 were compared. Due to operational problems with the green roof tipping bucket system, comparable monitoring results were only available from event 8 (Table 7). Additional failures of the monitoring system also occurred later (events 11, 12,15 and 16).

During the start-up period of the green roof, irrigation significantly reduced its hydraulic efficiency (Perales-Momparler et al., 2014). Nevertheless, even though irrigation was carried out to ensure the proper development of the vegetation, volumetric efficiencies of up to $50 \%$ were achieved from the green roof. When irrigation operations were less frequent (winter and spring, events 10, 13, 14), the volumetric efficiency rose. However, when event 17 occurred at the end of the summer and after 3 months without rainfall, the green roof was again being irrigated, so the efficiency for this last recorded event fell to $55 \%$. These results 
1 highlight the impact of irrigation on the green roof performance, and the 2 importance of planting with vegetation with a very low water demand.

3 Time delays and peak flow reductions were observed between the start of 4 discharge from the green roof and from the conventional roof. Fig. 2 shows the 5 hydraulic behaviour of both roofs during a typical short torrential shower 6 recorded in April 2013. The total rainfall volume was $29 \mathrm{~mm}$ and the maximum $7 \quad 10$-minute intensity was $43 \mathrm{~mm} / \mathrm{h}$. Only $26 \%$ of the rainfall volume was detained 8 by the conventional roof whereas $86 \%$ efficiency was achieved in the green roof. 9 Peak flow reduction is also significant. As can be observed, conventional runoff was seven times greater than that from the green roof.

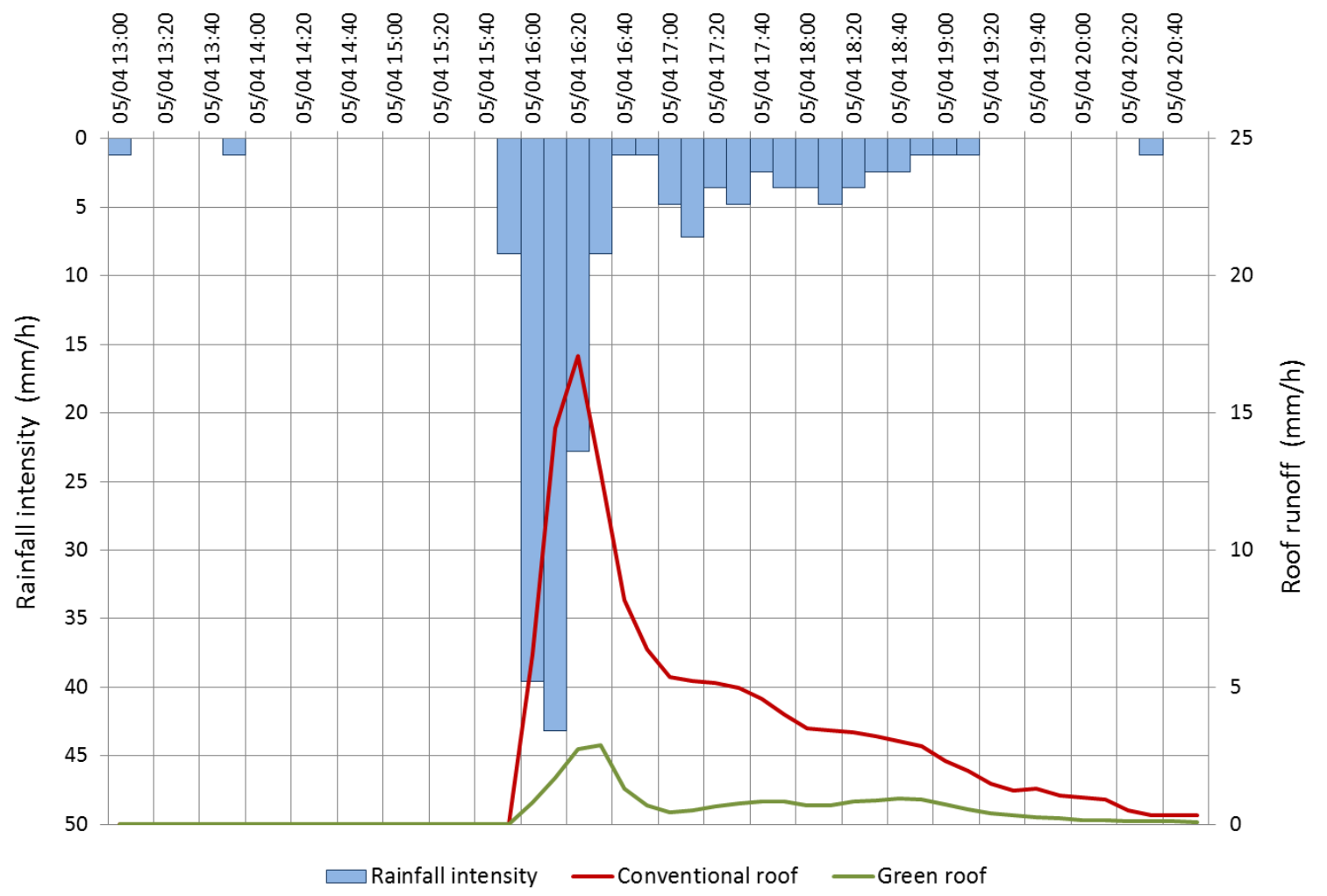

Fig. 2. Comparison between the green roof and the conventional roof runoff during rainfall event 13 ( $5^{\text {th }}$ April 2013).

In Benaguasil, the infiltration basin at the industrial estate (B3) coped with the runoff generated from every event and no discharge from this site was observed. The detention basins at Costa Ermita (B1) were similarly efficient and runoff spilled to the downstream sewer system only once during the whole period (event 1).

The rainwater tank collected water during all storm events to be used later to irrigate the adjacent park. Pumping was not required because the park was at a lower level giving water and energy savings. Fig. 3 shows the stored volume during the monitoring period. In May 2013, the level probe failed and the tank 
1 was partially emptied for maintenance. During the summer, almost $2.5 \mathrm{~m}^{3}$ of

2 water were reused for irrigation.

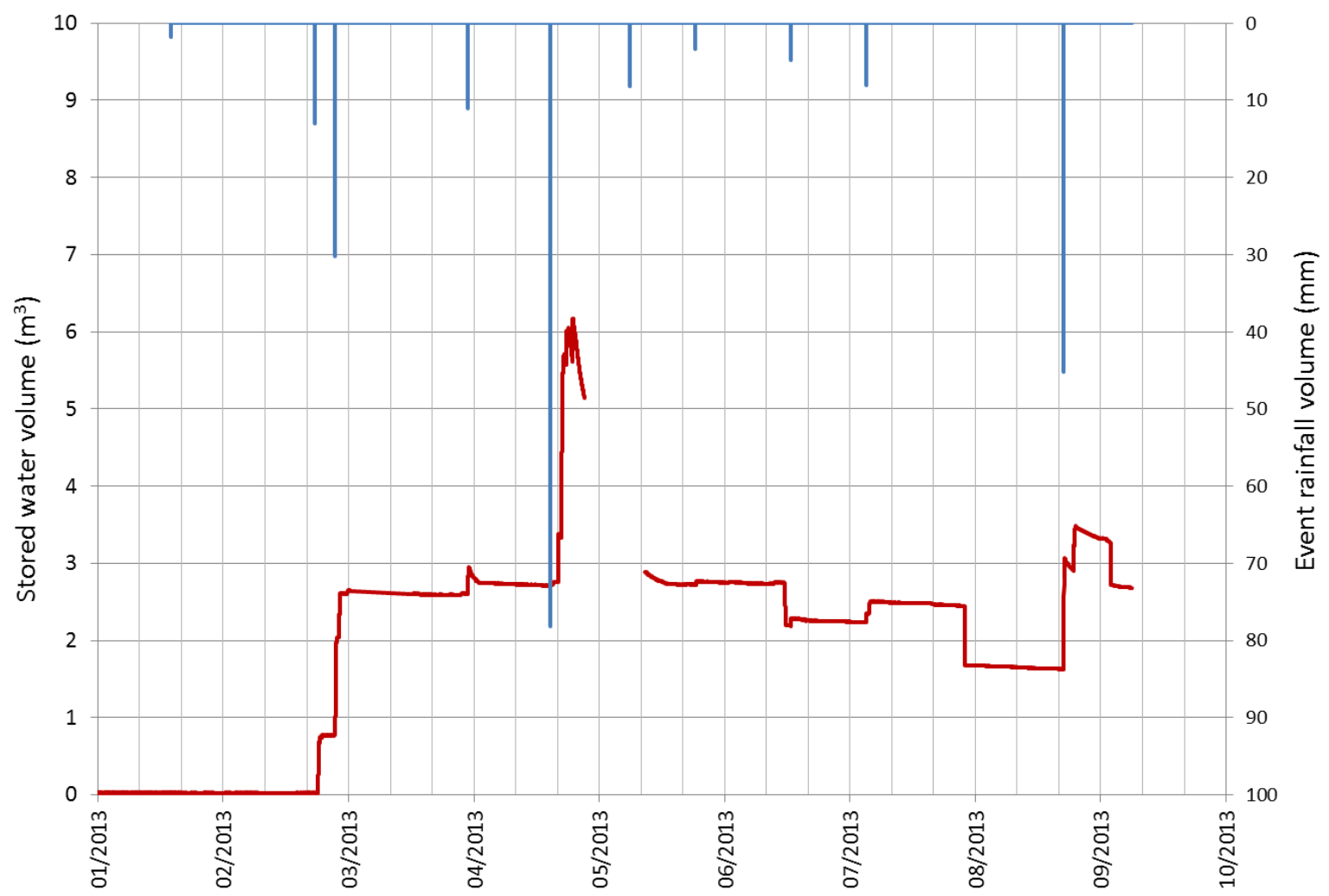

Fig. 3. Stored water volume at the rainwater harvesting tank.

\subsection{Water quality results}

The water quality results indicated that runoff from roadways (X12 in Xàtiva Sports City and X22 in North Ring Road) did not differ significantly from each other $(p>0.05)$ but they were more contaminated than the other inlets (X11 and X21) (Fig. 4). For example, the concentration of organic matter was high and highly variable, ranging between 72 and $1600 \mathrm{mg} \cdot \mathrm{L}^{-1}$ (Fig. 4). COD was strongly linearly correlated with TSS $\left(r_{\text {Pearson }}^{2}=0.76\right)$ and VSS $\left(r_{\text {Pearson }}^{2}=0.80\right)$. TP was also correlated with TSS $\left(r_{\text {Pearson }}^{2}=0.70\right)$ because of the sorption processes involving both variables (Kadlec and Wallace, 2009). However, as expected, no correlation was found between TN and TSS because the dissolved species of nitrogen (ammonia and nitrates) have low sorption capacity. All the water quality concentrations reduced in the swales between inlet and outlet showing the effectiveness of this system: the poorest performance was for TSS $(35 \%)$ whereas the best was for TN with a $60 \%$ concentration reduction.

It is known that antecedent dry period, storm intensity and traffic density are relevant factors influencing runoff quality (Kim et al., 2006; Brodie and Dunn, 2010; Zuo et al., 2011). No significant differences were found between water quality variables in $X 12$ and $X 22(p>0.05)$, so all the values obtained from both 
roads were used in a multivariate analysis which showed that antecedent dry period was the most significant variable for TP and TN whereas rainfall intensity was the most influential for COD and TSS. In fact, some values of TSS were much higher (more than $1000 \mathrm{mg} \cdot \mathrm{L}^{-1}$ ) than the maximum observed in other studies under different climatic conditions (Stagge et al, 2012).
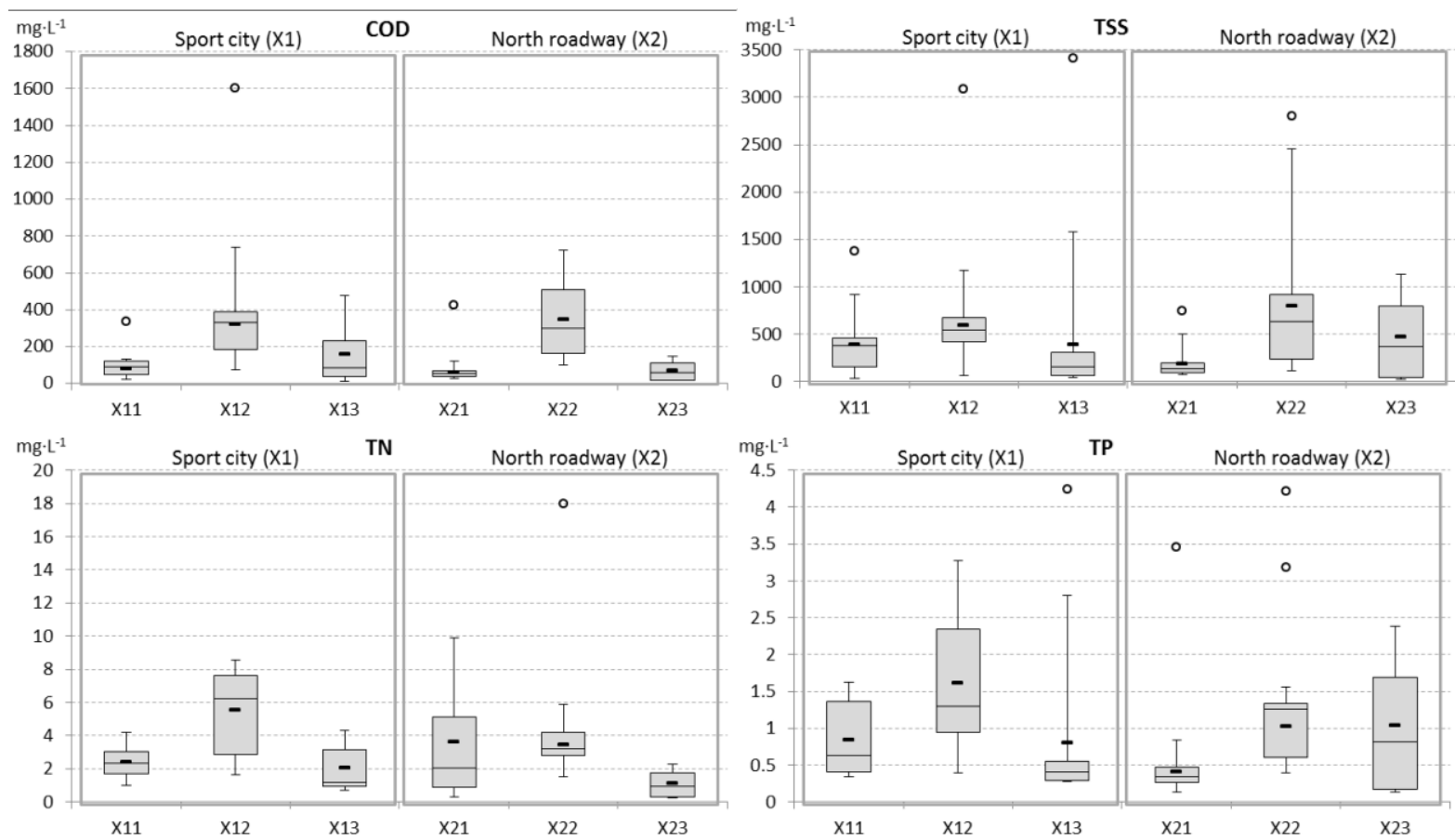

Fig. 4. Water quality variables of runoff at sites X1 and X2.

The influence of traffic can be seen from a comparison between sites with different source of pollutants (X11: recreational area, X21: residential/low traffic area, and $\mathrm{X} 12-\mathrm{X} 22$ roadways with intense traffic). The statistical analysis revealed significantly higher $(p<0.05)$ levels of COD, TSS and TP in runoff from roadways with traffic. For instance, COD from X22 was six times higher than X21 (Fig. 4), showing the presence of hydrocarbons, plastics, etc. from vehicles. In contrast, TN concentration did not differ significantly between roadways with high and low traffic, a fact that may be related to the greater mobility of nitrogen compounds. On the other hand, runoff from the recreational area (X11) had lower concentrations of COD and TN than the roadways $(p<0.05)$ but similar levels of TSS and TP $(p>0.05)$, probably due to soil erosion from gardens, especially during very intense rainfall events.

With regard to the green roof results, box-plots of COD, TSS, TN and TP are shown in Fig. 5. The comparison between the water quality data from the green roof (X311) and the non-vegetated roof (X321) in the start-up period clearly showed the green roof in a poor light, except for TSS which was usually below $20 \mathrm{mg} \cdot \mathrm{L}^{-1}$. There were no significant differences between rain water (X33) and roof water $(p>0.05)$. However, nutrients (TN and TP) and organic matter (COD) 
were notably higher in runoff from the green roof $(p<0.05)$, showing the washing of dissolved substances. This washing effect declined after some time: for instance, COD concentrations decreased from values higher than $350 \mathrm{mg} \cdot \mathrm{L}^{-1}$ to $450 \mathrm{mg} \cdot \mathrm{L}^{-1}$ and similar trends were observed for TN and TP (see temporal 5 evolution of $\mathrm{X} 31$ in Fig. 5). After 17 rainfall events (total volume drained $9.0 \mathrm{~m}^{3}$ according to Table 7), TN and TP concentrations were reduced by approximately one half, a decrease also observed by Malcolm et al. (2014). Nevertheless, in spite of presenting higher concentrations of COD and nutrients, if the concentration remained constant (worst case scenario), the total loads drained by the green roof are lower than that drained by the non-vegetated roof, because of the higher volumetric efficiency of the green roof. The roof material was a specific green roof substrate with high organic matter content and nutrients added to ensure plant growth. The ideal situation for a green roof is one in which nutrients and humidity supplied by atmospheric deposition (wet and dry) are enough to maintain vegetation and soil microorganism activity; the role of a well-developed green roof as a trap of pollutants could be relevant in this case. But one of the uncertainties in the use of these infrastructures in a Mediterranean climate is related to rainfall intensity and interval: if there is a heavy rainfall event, nutrients previously settled by dry deposition will be quickly washed out, so a pool of nutrients is necessary inside the substrate, at least until the vegetation matures. In any case, the ability of the green roof to improve water quality from rainfall is still a matter of debate (Rowe, 2011). Nevertheless there are many reasons to encourage the installation of green roofs such as greater energy efficiency, aesthetics, improvement to the city's climate, biodiversity enhancement, all these improving the quality of city life (Berndtsson et al. 2006).
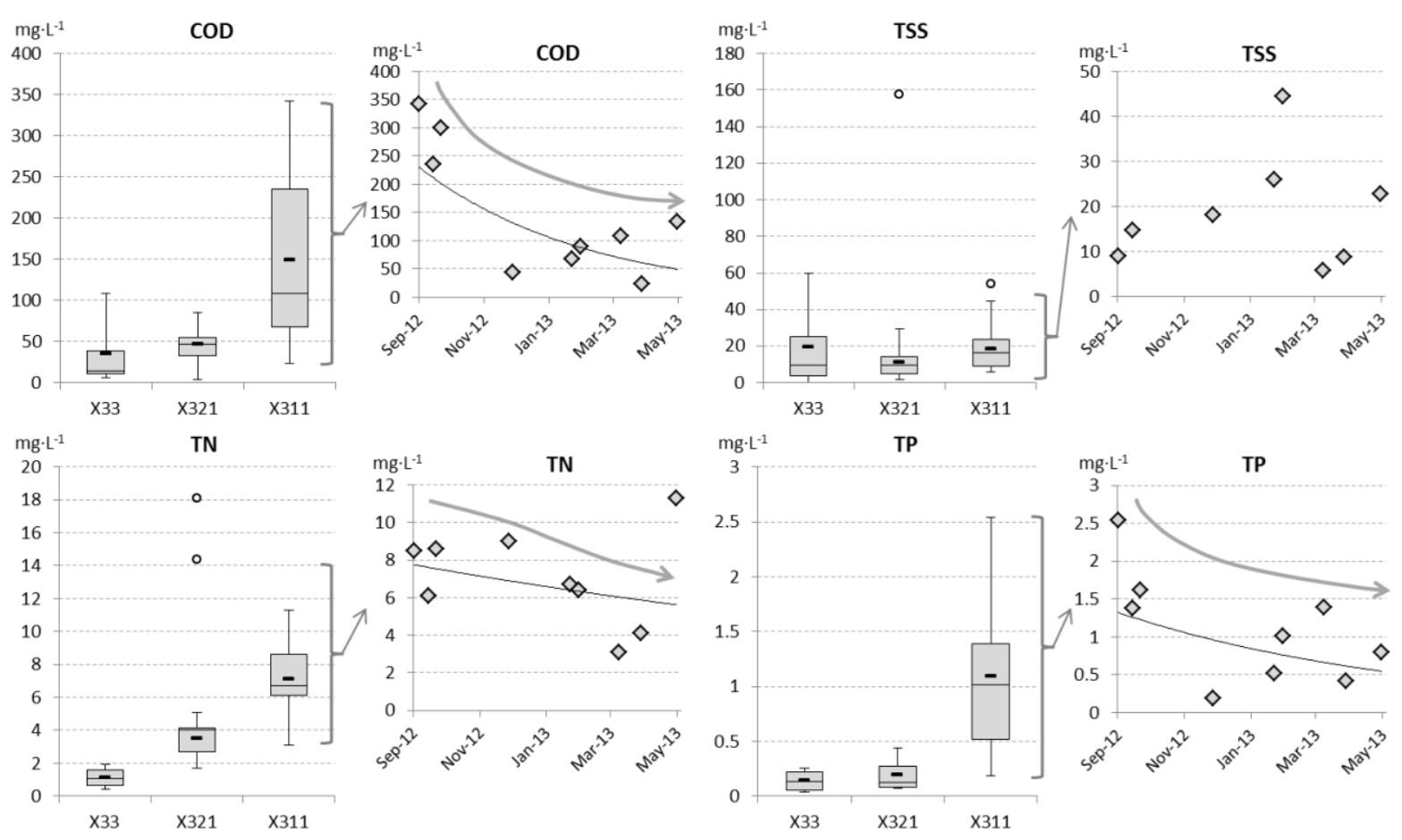
Fig. 5. Water quality variables of runoff in site X3 (X33: rainwater; X321: conventional roof; X311: green roof).

In Benaguasil, infiltration basins in B1 registered only one spill over the whole period showing their ability to reduce not only flow discharges to sewer system, but also the pollutant mass loading. These basins received high load of TSS and particle-bounded pollutants (Table 8 ) from the erosion of soil. The proximity of a big forested zone upstream influenced the quality of runoff with the highest TN and TSS mean concentration of all sites. These basins played a very important role in pollutant sequestration because of their $100 \%$ volumetric efficiency. This in turn reduced the loads from the sewer system to the local waste water treatment plant and/or discharges to the receiving water body, contributing to an improvement of sewage treatment facilities and also the river ecosystem.

In contrast, washing of roofs and pavement of industrial estate (B3 in Table 8) provided runoff concentrations lower than Costa Ermita (B1), showing high differences depending on the different characteristics of the catchment area.

All sampling sites, both in Xàtiva and Benaguasil, shared the common characteristic of poorly biodegradable organic matter, with the $\mathrm{BOD}_{5} / \mathrm{COD}$ ratio lower than 0.22 .

The last showcases are the harvesting tanks in Benaguasil (B22) and Xàtiva (X34). The tanks collected rain water that could be used for irrigation in green zones because microbiology indicators, Escherichia coli and intestinal nematodes (Table 8), were below most limiting values of the Spanish water reuse law (R.D.1620/2007: $100 \mathrm{CFU} / 100 \mathrm{~mL}$ for Escherichia coli and $1 \mathrm{egg} / 10 \mathrm{~L}$ for intestinal nematodes). Despite the fact that this regulation only concerns treated wastewater, it is commonly used for reference values.

Table 8. Mean and standard deviation of quality variables at sampling points in Infiltration-detention basins B1 and B3 and harvesting tanks in Benaguasil (B22) and Xàtiva (X34).

\begin{tabular}{lrrlrl}
\hline Water quality variable & \multicolumn{1}{c}{ B1 } & B3 & B22 & X34 \\
\hline COD $\left(\mathrm{mg} \cdot \mathrm{L}^{-1}\right)$ & $1158 \pm 622$ & $152 \pm 155$ & & \\
BOD $_{5}\left(\mathrm{mg} \cdot \mathrm{L}^{-1}\right)$ & $63 \pm 50$ & $34 \pm 28$ & & & \\
TN $\left(\mathrm{mg} \cdot \mathrm{L}^{-1}\right)$ & $13,49 \pm 7,00$ & $4,02 \pm 3,29$ & & \\
TP $\left(\mathrm{mg} \cdot \mathrm{L}^{-1}\right)$ & $2,49 \pm 1,88$ & $0,47 \pm 0,44$ & & \\
TSS $\left(\mathrm{mg} \cdot \mathrm{L}^{-1}\right)$ & $2252 \pm 1349$ & $84 \pm 90$ & & & \\
VSS $\left(\mathrm{mg} \cdot \mathrm{L}^{-1}\right)$ & $330 \pm 163$ & $23 \pm 20$ & & & \\
Turbidity $(\mathrm{NTU})$ & $1325 \pm 962$ & $135 \pm 184$ & & & \\
Conductivity $\left(\mu \mathrm{HS} \cdot \mathrm{cm}^{-1}\right)$ & $377 \pm 262$ & $198 \pm 90$ & $246 \pm 50$ & $44 \pm 6$ \\
Temperature $\left({ }^{\circ} \mathrm{C}\right)$ & $16,0 \pm 6,3$ & $16,6 \pm 5,9$ & $21,6 \pm 2,4$ & $21,4 \pm 3,2$ \\
pH & $7,60 \pm 0,31$ & $6,88 \pm 0,32$ & $7,48 \pm 0,58$ & $6,97 \pm 0,58$ \\
DO (mg $\left.\cdot \mathrm{L}^{-1}\right)$ & $5,98 \pm 3,47$ & $5,96 \pm 3,77$ & $7,58 \pm 2,04$ & $8,36 \pm 0,84$ \\
$\%$ Sat DO & $57 \% \pm 29 \%$ & $58 \% \pm 32 \%$ & $85 \% \pm 20 \%$ & $94 \% \pm 7 \%$ \\
Escherichia Coli & & & & $2 \pm 4$ & $8 \pm 11$
\end{tabular}


(CFU/100 mL)

Intestinal nematodes

(egg/10 L)

\subsection{Overall assessment of the data}

The data show that the pilots SuDS have good hydraulic performance under a typical Mediterranean climate. One of the most important barriers for their implementation in this area was the lack of local experience and the uncertainty of their performance (Castro-Fresno et al., 2013). The results show that SuDS are also suitable and reliable under a climate with small rainfall totals but with torrential events. Overall the volumetric hydraulic performances achieved were quite high with retention very close to $100 \%$ except for the green roof. Peak flow control is also important and rainwater harvesting and reuse has also been shown to have potential in the pilots.

From the standpoint of water quality, the study has allowed the degree of pollution to be distinguished between three types of urban surface: roofs, gardens and roadways. The latter generated much higher concentrations of organic matter (up to $1600 \mathrm{mg} \cdot \mathrm{L}^{-1}$ of COD) and suspended solids (up to $3083 \mathrm{mg} \cdot \mathrm{L}^{-1} \mathrm{SST}$ ), reflecting the influence of traffic (Kayhanian et al., 2012). The fact that runoff from gardens was similar to that from the road in some rain event is due to torrential rainfall and its erosive power, characteristics typical of Mediterranean climates. Conversely, the differences between the types of urban surfaces were not so clear for total nitrogen, for which the values were around $4 \mathrm{mg} \cdot \mathrm{L}^{-1}$, revealing the importance of atmospheric deposition in this variable.

Results show that grass swales and infiltration basins improve water quality before it is discharged to the sewer system (maximum COD discharged of $478 \mathrm{mg} \cdot \mathrm{L}^{-1}$ ) although this improvement depends on the hydraulic retention time. This quality improvement is sufficient to meet discharge municipal ordinances (e.g. COD lower than $1000 \mathrm{mg} \cdot \mathrm{L}^{-1}$, typical value of discharge requirement) and to ensure the proper functioning of the waste water treatment plant (WWTP), thus minimizing impacts on the receiving waterbody. Consequently, an important part of the contaminated load is retained and naturally treated by the SuDS infrastructure, so polluted loads discharged to the sewer system or any receiving water body are significantly reduced.

However, the efficiency of these systems should not be measured only in terms of the reduction of pollutant concentration but also in the reduction of total load spilled (Berndtsson et al. 2006). Data gathered from site X3 is a good example for this: although runoff from the vegetated part (green roof) has higher pollutant concentrations than its non-vegetated counterpart, less runoff volume is discharged, resulting in less total pollution leaving the site.

Furthermore the presence of SuDS attenuates the peak of the pollution load entering a WWTP thus helping to reduce any impact on its proper operation. This 
improvement of WWTP operation achieved by SuDS could also be achieved by building storm tanks at the WWTP inlet; it is likely that the construction and operation costs associated with the pumping and treatment of the stored water would be higher and a tank cannot provide any community or biodiversity benefits.

Removing invasive vegetation and replacement of a small number of dead plants

have been the main maintenance operations on the green roof (2-3 times per year). Sediment, washed from higher up its catchment, has had to be removed from site B3 after each storm. Sediments from the hill also accumulate in site B1 although removal is expected to be required only every 5 years. In both cases, SuDS prevent those sediments from entering the sewer network from where removal would be much more difficult and expensive. For the rest of the sites, only regular vegetation management and trash removal has been required to date (three years after construction), with visual inspections confirming the good performance of inlets, outlets and the complete infiltration of water shortly after rainfall. All sites were spray irrigated for the first 2-3 years after planting to help their establishment. As the plants used are drought tolerant, it is expected that they will need little additional water from now on, except during prolonged droughts as expected in summer in both locations.

Lessons learned through the construction, monitoring, operation and maintenance of the showcase sites will form the basis for future developments in the process of the paradigm shift leading to a broader uptake of SuDS in Spain.

As a very practical example, monitoring results from the green roof retrofitted in Xàtiva guided the design and operation of a green roof retrofitted later in Benaguasil as part of another EU funded project, E²STORMED (1C-MED12-14, www.e2stormed.eu). For instance, in order to minimize the leaching of nutrients, the substrate composition used in this second green roof was different: with soil of lower nutrient content and the use of controlled release fertilizers. In terms of operation, irrigation is now controlled automatically by a soil moisture sensor and vegetation water demand so that manual irrigation is no more needed. The Benaguasil green roof is currently being monitored for its hydrology coupled with energy consumption of the air conditioning system to analyze energy savings produced by the green insulation against the baseline situation represented by the conventional roof (Alfonso et al., 2015).

\section{Stakeholders perceptions on showcases as transition promoters}

The transition to more sustainable stormwater management is a slow process that requires a wide perspective and the participation of different stakeholders, in which the contribution that science and research are continuously providing is precious (Barbosa et al., 2012). 
Within the framework of the AQUAVAL project, a Regional Working Group was created (led by Xàtiva and Benaguasil City Councils) involving actors from across the region in the water sector, public and private. As explained in PeralesMomparler et al. (2015), this group evolved and had continuity within the $\mathrm{E}^{2} \mathrm{STORMED}$ project. The total number of actors was downsized to allow for productive dialogue, whilst incorporating key stakeholders on environment, urban planning and the energy sector with represented at political, technical and 8 managerial levels. These stakeholders had the opportunity to visit the showcase sites and were presented with monitoring results as they became available. Their perceptions were informally collected and considered for future actions such as the development of a Strategic Action Plan for Benaguasil.

Regional Working Group members highlighted the importance of demonstration projects as promoters of the transition, in particular when monitoring results are presented in an understandable way for decision makers. The AQUAVAL showcase sites have influenced not only local practice, but more importantly, the support for SuDS in recent regional legislation which dictates that the use of SuDS must be encouraged in all municipalities of the Valencian region (Resolution of $31^{\text {st }}$ October 2013). In this piece of legislation, the Valencian Regional Government presents Benaguasil and Xàtiva showcases as a model to be followed. It is also worth highlighting the role of the Valencia City Council (Diputación de Valencia), that being a member of the Regional Working Group, actively disseminates the $E^{2}$ STORMED project events and outcomes using the "Valencian municipalities towards sustainability network" website (i.e. http://www.dival.es/xarcia/content/sistemas-de -drenaje-sostenible-enbenaguasil-proyecto-europeo-e2stormed).

In addition, in order to survey the importance given by stakeholders to demonstration activities, a questionnaire was distributed amongst participants on a national workshop on sustainable urban drainage held in Valencia during April 2015 within the framework of the $E^{2}$ STORMED project. For this survey 6 questions were analyzed: two related to stakeholders' classification (age group and professional affiliation), three to provide their agreement level (completely agree, agree, neutral, disagree and completely disagree) on the importance of demonstration activities (pilot construction, water quantity monitoring and water quality monitoring), and one to choose the single most important activity amongst the latter. For this last question, two additional choices were added: the possibility to have a decision making tool available or none of the above. Questionnaires were distributed electronically few days after the workshop to the 79 attendees.

The questionnaire responses demonstrate the relevance of showcases in a similar way to the ones presented herein. A high response was achieved (44\%), with respondents belonging to 10 professional affiliations (23\% local government professional; $20 \%$ consultant; $20 \%$ researcher/academic; $14 \%$ water utility; $3 \%$ regional government professional; $3 \%$ national government professional, $3 \%$ 
tradesman; 3\% manufacturer; 3\% student; $8 \%$ others) and from all age group categories (3\% 18-24; 17\% 25-34; 46\% 35-44; 29\% 45-54; 6\% 55-64).

Responders highly agreed with the importance of demonstration activities. When asked about how much they agreed with the importance of constructing demonstration sites, $89 \%$ completely agreed and $9 \%$ agreed. This positivism was repeated, although not as forcefully when asked about the importance of water quantity and quality monitoring activities. In both cases, $66 \%$ completely agreed and $31 \%$ agreed. When asked to choose the most important demonstration activity, $57 \%$ opted for pilot construction, $11 \%$ quantity monitoring and $9 \%$ quality monitoring.

At this point it is worth recalling that SuDS provide collective benefits (flood protection, water quality, landscaping, etc.), require collective efforts and challenge the traditional means of stormwater governance, all this making the interaction of stakeholders fundamental. In other words, poor interaction between stakeholders is incompatible with such enhanced or smarter governance which is by itself also a form of innovation in addition to the innovation brought by means of new constructions and technologies. The way stakeholders have been engaged and how their understanding of the showcase sites as transition promoters was assessed, smooths the difficulties that innovation faces in being presented, understood, and endorsed by professionals and decision-makers. The result is that SuDS are now perceived as a realistic storm water management alternative for both retrofitting and new urban developments in the Valencian region.

\section{Conclusions}

This paper addresses the issue of providing scientific knowledge and practical approaches to counteract a number of undesired effects of existing and planned urbanization related to the impervious surfaces generated (buildings, roads, parking lots, etc.).

SuDS, as ecological urban infrastructures, bring together technologies, engineering and governance, helping in the management of aspects of storm water quantity and quality in a comprehensive and sustainable manner while adding multiple additional benefits.

Although SuDS are key in the transition towards regenerative urban built environments, there is still limited evidence on the performance of these systems and a need to quantify their acknowledged benefits, i.e. in terms of flood protection and water quality among others.

In this context, the six showcase sites presented herein provide proof of concept in the field both in the quantitative and qualitative phases of the performance of 
SuDS as well as providing compelling examples of how this new knowledge enhances storm water governance. Furthermore, the engagement of stakeholders in their development has confirmed the strategic importance of the construction and monitoring of demonstration sites.

Examples of the current and potential impact of the knowledge generated are their influence on the legislative support given by the Valencian Regional Government to SuDS and the suitability of the data collected to calibrate models (e.g. of green roof efficiency in attenuating the storm peak) which could later be used to assess larger scale SuDS retrofitting agendas.

Beyond all the detailed benefits of the demonstration sites monitored, in a broad sense, they have been drivers of innovation and formed the basis of a new storm water paradigm in a Spanish region which will certainly benefit from it in the near future, serving as a reference to other urban areas in the Mediterranean.

\section{Acknowledgements}

This research has been conducted as part of the Life+ program project "AQUAVAL: Sustainable Urban Water Management Plans, promoting SUDS and considering climate change, in the province of Valencia" (Life08ENV/E/000099) and the MED program project " $E^{2} S T O R M E D$ : Improvement of energy efficiency in the water cycle by the use of innovative storm water management in smart Mediterranean cities" (1C-MED12-14), both supported by European Regional Development Fund (ERDF) funding of the European Union.

\section{References}

Alfonso, D., Peñalvo, E., Pérez-Navarro, A., Valencia, I., 2015. Energy efficiency effects of green roofs in buildings. An experimental assessment for Mediterranean areas. Proceedings of the IWRA World Water Congress XV, Edinburgh, Scotland.

Anderson, J., Iyaduri, R., 2003. Integrated urban water planning: big picture planning is good for the wallet and the environment. Water Science and Technology : a Journal of the International Association on Water Pollution Research, 47, 7-8, 19-23.

Andrés-Doménech, I., Montanari, A., Marco, J. B., 2010. Stochastic rainfall analysis for storm tank performance evaluation. Hydrol. Earth Syst. Sci., 14, 1221-1232. http://dx.doi.org/10.5194/hess-14-1221-2010. 
APHA, Standard methods for the examination of water and wastewater, 1991. $17^{\text {th }}$ ed., American Publish Health Associaton. Washington, DC (USA).

Arnbjerg-Nielsen, K., Willems, P., Olsson, J., Beecham, S., Pathirana, A., Bülow, G.I., Madsen, H., Nguyen, V.T.V., 2013. Impacts of climate change on rainfall extremes and urban drainage systems: a review. Water Sci. Technol. 68 (1), 1628. http://dx.doi.org/10.2166/wst.2013.251.

Barbosa, A.E., Fernandes, J.N., David, L.M., 2012. Key issues for sustainable urban stormwater management. J. Wat. Res. 46, 6787-6798.

http://dx.doi.org/10.1016/j.watres.2012.05.029.

Berndtsson, J.C., Emilsson, T., Bengtsson, L., 2006. The influence of extensive vegetated roofs on runoff water quality. Sci. Tot. Environ. 355, 48-63. http://dx.doi.org/10.1016/j.scitotenv.2005.02.035.

Binney, P., Donald, A., Elmer, V., Ewert, J., Phillis, O., Skinner, R., Young, R., 2010. IWA Cities of the Future Program. Spatial Planning and Institutional Reform Discussion Paper for the World Water Congress. Spatial Planning and Institutional Reform Working Group Report, Montreal, Canada. http://www.iwahq.org/contentsuite/upload/iwa/document/updated\%20iwa\%20s patial\%20planning\%20and\%20institutional\%20reform\%20group\%20montreal\% 20discussion\%20paper.pdf (accessed 01.06.15).

Brodie, I.M., Dunn, P.K., 2010. Commonality of Rainfall Variables Influencing Suspended Solids Concentrations in Storm Runoff from Three Different Urban Impervious Surfaces, J. Hydrol. 387, 202-211. http://dx.doi.org/10.1016/j.jhydrol.2010.04.008.

Brown, R.R., Farrelly, M.A., 2009. Delivering sustainable urban water management: a review of the hurdles we face. Water Sci. Technol. 59 (5), 839e846. http://dx.doi.org/10.2166/wst.2009.028.

Brown, R.R., Keath, N., Wong, T.H.F., 2009. Urban water management in cities: historical, current and future regimes. Water Sci. Technol. 59, 5, 847-855. http://dx.doi.org/10.2166/wst.2009.029.

Burns, M.J., Fletcher, T.D., Walsh, C.J., Ladson, A.R., Hatt, B.E., 2012. Hydrologic shortcomings of conventional urban stormwater management and opportunities for reform. Land. Urb. Plan. 105, 230-240. http://dx.doi.org/10.1016/j.landurbplan.2011.12.012.

Casal-Campos, A., Jefferies, C., Perales-Momparler, S., 2012. Selecting SUDS in the valencian region of Spain. Water Pract. Technol. 7, 1. http://dx.doi.org/10.2166/wpt2012.001 (published online).

Castro-Fresno, D., Andrés-Valeri, V. C., Sañudo-Fontaneda, L. A., RodríguezHernández, J., 2013. Sustainable drainage practices in Spain, specially focused on pervious pavements, Water, 5, 67-93. http://dx.doi.org/10.3390/w5010067. 
1 Charlesworth, S.M., 2010. A review of the adaptation and mitigation of global 2 climate change using sustainable drainage in cities. Journal of Water and Climate 3 Change, 1, 3, 165-180. http://dx.doi.org/10.2166/wcc.2010.035.

4 Charlesworth, S.M., Perales-Momparler, S., Lashford, C., Warwick, F., 2013. The 5 sustainable management of surface water at the building scale: preliminary 6 results of case studies in the UK and Spain. J. Water Supply Res. Technol. 62 7 (8), 534-544. http://dx.doi.org/10.2166/aqua.2013.051.

8 Chouli, E., Aftiasb, E., Deutscha, J.C., 2007. Applying storm water management 9 in Greek cities: learning from the European experience. Desalination 210, 61e68. http://dx.doi.org/10.1016/j.desal.2006.05.033.

du Plessis, C., 2012. Towards a regenerative paradigm for the built environment. Building Research \& Information, 40, 1, 7-22. http://dx.doi.org/10.1080/09613218.2012.628548

European Commission, 2010. Toledo reference document on integrated urban regeneration and its strategic potential for a smarter, more sustainable and socially inclusive urban development in Europe. Toledo, 22 June 2010. http://ec.europa.eu/regional_policy/archive/newsroom/pdf/201006_toledo_decla ration_en.pdf (accessed 01.06.15).

Frantzeskaki, N., Loorbach, D., Meadowcroft, J., 2012. Governing societal transitions to sustainability: Transition management as a governance approach towards pursuing sustainability. Int. J. Sustainable Development, 15, 1-2, 19-36.

Halpin, E., Escuder, I., 2015. Smart governance of infrastructure programs: facing the next generation of challenges and succeeding. Proceedings of the 25 ICOLD Congress. Norway.

Hunt, D.V.L., Rogers, C.D.F., 2005. Barriers to sustainable infrastructure in urban regeneration. Engineering Sustainability, 158, 2, 67-81.

Jefferies C., Duffy A.M., 2011. The SWITCH Transition Manual. ISBN 978-1899796-23-6. http://www.switchurbanwater.eu/outputs/pdfs/W13_GEN_MAN_D1.3.4_SWITCH_Transition_Manual.pdf (accessed 01.06.15).

Jim, C.Y., 2004. Green-space preservation and allocation for sustainable greening of compact cities. Cities, 21, 4, 311-320. http://dx.doi.org/10.1016/j.cities.2004.04.004

Kadlec, R.H., Wallace, S.C., 2009. Treatment Wetlands (2 ${ }^{\text {nd }}$. Edition). CRC Press. Taylor \& Francis Group. ISBN 978-1-56670-526-4.

Kayhanian, M., Fruchtman, B.D., Gulliver, J.S., Montanaro, C., Ranieri, E., Wuertz, S., 2012. Review of highway runoff characteristics: Comparative analysis and universal implications. Water Research, 46, 6609-6624. http://dx.doi.org/10.1016/j.watres.2012.07.026 
1 Kim, L.H., Zoh, K.D., Jeong, S.M., Kayhanian, M., Stenstrom, M. K., 2006.

2 Estimating Pollutant Mass Accumulation on Highways during Dry Periods, J.

3 Environ. Eng. 132, 985-993. http://dx.doi.org/10.1061/(ASCE)0733-

4 9372(2006)132:9(985).

Lamera, C., Becciu, G., Rulli, M.C., Rosso, R., 2014. Green roofs effects on the urban water cycle components. J. Pro. Eng. 70, 988-997. http://dx.doi.org/10.1016/j.proeng.2014.02.110.

Li, F., Wang, R., Paulussen, J., Liub, X., 2005. Comprehensive concept planning of urban greening based on ecological principles: a case study in Beijing, China. Landscape and Urban Planning 72, 325-336. http://dx.doi.org/10.1016/j.landurbplan.2004.04.002.

Loorbach, D., Rotmans, J., 2010. The practice of transition management: Examples and lessons from four distinct cases. Futures 42, 237-246. http://dx.doi.org/10.1016/j.futures.2009.11.009.

Loorbach, D., van Bakel, J. C., Whiteman, G., \& Rotmans, J. 2010. Business strategies for transitions towards sustainable systems. Business Strategy and the Environment, 19, 2, 133-146. http://dx.doi.org/10.1002/bse.645.

Malcolm, E.G., Reese, M.L., Schaus, M.H., Ozmon, I.M., Tran, L.M., 2014. Measurements of nutrients and mercury in green roof and gravel roof runoff. Ecol. Eng. 73, 705-712. http://dx.doi.org/10.1016/j.ecoleng.2014.09.030.

Millán, P., Nácher-Rodríguez, B., Hernández, C., Martín, M., Vallés, F.J., AndrésDoménech, I., Perales-Momparler, S., 2013. Comparative analysis of runoff from a permeable pavement and from a conventional road. In: Vallés-Morán, F.J., Andrés-Doménech, I., Escuder-Bueno, I., López-Jiménez, P.A., Marco, J.B. (Eds.), 2013, III Jornadas de Ingeniería del Agua, La protección contra los riesgos hídricos, vol. 2, ISBN 978-84-267-2071-9, pp. 131 138 (in Spanish).

Mitchell, V.G., 2006. Applying Integrated Urban Water Management Concepts: A Review of Australian Experience. Environmental Management 37(5), 589-605. http://dx.doi.org/10.1007/s00267-004-0252-1.

Nevens, F., Frantzeskaki, N., Gorissen, L., Loorbach, D., 2013. Urban transition labs: co-creating transformative action for sustainable cities. J. Clean. Prod. 50, 111e122. http://dx.doi.org/10.1016/j.jclepro.2012.12.001.

Norton, B.A., Coutts, A.M., Harris, R.J., Hunter, A.M., Williams, N.S.G., 2015. Planning for cooler cities: $A$ framework to prioritise green infrastructure to mitigate high temperatures in urban landscapes. Landscape and Urban Planning 134, 127-138. http://dx.doi.org/10.1016/j.landurbplan.2014.10.018.

Novotny, V., Ahern, J., Brown, P., 2010. Water centric sustainable communities: planning, retrofitting, and building the next urban environment. John Wiley \& Sons, Inc. New Jersey. ISBN 978-0-470-47608-6. 
Pahl-Wostl, C., Tabara, D., Bouwen, R., Craps, M., Dewulf, A., Mostert, E., Ridder, D., Taillieu, T., 2008. The importance of social learning and culture for sustainable water management. Ecol. Econ. 64,33, 484e495.

4 http://dx.doi.org/10.1016/j.ecolecon.2007.08.007.

Perales-Momparler, S., Andrés-Doménech, I., Andreu, J., Escuder-Bueno, I.,2015. A regenerative urban stormwater management methodology: the journey of a Mediterranean city. Journal of Cleaner Production, 109 (2015) 174189. $h t t p: / / d x$. doi.org/10.1016/j.jclepro.2015.02.039.

Perales-Momparler, S., Hernández-Crespo, C., Vallés-Morán, F., Martín, M., Andrés-Doménech, I., Andreu Á., J., Jefferies, C., 2014. SuDS Efficiency during the Start-Up Period under Mediterranean Climatic Conditions. Clean-Soil Air Water 42, 2, 178-186. http://dx.doi.org/10.1002/clen.201300164.

Perales-Momparler, S., Jefferies, C., Perigüell-Ortega, E., Peris-García, P.P., Muñoz-Bonet, J.L., 2013. Inner-city SUDS retrofitted sites to promote sustainable stormwater management in the Mediterranean region of Valencia: AQUAVAL (Life+ EU Programme). NOVATECH Conference, Lyon, France.

Potter, K., Ward, S., Shaw, D., Macdonald, N., White, I., Fischer, T., Butler, D., Kellagher, R., 2011. Engineers and planners: sustainable water management alliances. Eng. Sustain. 164 (ES4), 239-247.

http://dx.doi.org/10.1680/ensu.2011.164.4.239.

Radywyl, N., Biggs, C., 2013. Reclaiming the commons for urban transformation. J. Clean. Prod. 50, 159-170. http://dx.doi.org/10.1016/j.jclepro.2012.12.020.

Royal Decree 1620/2007 of 7th December establishing the juridical regime for treated water reuse. [Real Decreto 1620/2007, de 7 de diciembre, por el que se establece el régimen jurídico de la reutilización de las aguas depuradas.] Boletín Oficial del Estado 294, 2007, 50639-50661.

Reed, M.S., 2008. Stakeholder participation for environmental management: $A$ literature review. Biological Conservation, 141, 2417-2431. http://dx.doi.org/10.1016/j.biocon.2008.07.014.

Resolution of $31^{\text {st }}$ October 2013, of the Infrastructure, Territory and Environment Regional Ministry, submitting to public information the revision of the Territorial Action Plan on Flood Risk prevention for the Valencian Region. [Resolución de 31 de octubre de 2013, de la Consellería de Infraestructuras, Territorio y Medio Ambiente, por la que se somete a información pública la revisión del Plan de Acción Territorial sobre prevención del Riesgo de Inundación de la Comunitat Valenciana]. Diario Oficial de la Comunidad Valenciana 7159, 2013, 3428934290 .

Rowe, D.B., 2011. Green Roofs as a Means of Pollution Abatement. Environ. Pollut, 159, 2100-2110. http://dx.doi.org/10.1016/j.envpol.2010.10.029. 
Smith, A., Raven, R., 2012. What is protective space? Reconsidering niches in transitions to sustainability. Research Policy, 41, 1025-1036.

http://dx.doi.org/10.1016/j.respol.2011.12.012.

Stagge, J.H., Davis, A.P., Jamil, E., Kim, H., 2012. Performance of grass swales for improving water quality from highway runoff. Wat. Res. 46, 6731-6742. http://dx.doi.org/10.1016/j.watres.2012.02.037.

Terzakis, S., Fountoulakis, M.S., Georgaki, D., Albantakis, D., Sabathianakis, I., Karathanasis, A.D., Kalogerakis, N., Manios, T., 2008. Constructed wetlands treating runoff in the central Mediterranean region. Chemosphere 72, 141-149. http://dx.doi.org/10.1016/j.chemosphere.2008.02.044.

Tukker, A., Butter, M., 2007. Governance of sustainable transitions: about the 4(0) ways to change the world. J. Clean. Prod. 15, 1, 94-103. http://dx.doi.org/10.1016/j.jclepro.2005.08.016.

van der Brugge, R., Rotmans, J., 2007. Towards transition management of European water resources. Water Resour. Manag. 21, 1, 249-267. http://dx.doi.org/10.1007/s11269-006-9052-0.

Willke, H., 2007. Smart Governance: Governing the global knowledge society. The University of Chicago Press. Chicago, USA.

Winz, I., Trowsdale, S., Brierley, G., 2014. Understanding barrier interactions to support the implementation of sustainable urban water management. Urban Water Journal, 11, 6, 497-505. http://dx.doi.org/10.1080/1573062X.2013.832777.

Woolthuis, R., Hooimeijer, F., Bossink, B., Mulder, G., Brouwer, J., 2013. Institutional entrepreneurship in sustainable urban development: Dutch successes as inspiration for transformation. J. Clean. Prod. 50, 91-100. http://dx.doi.org/10.1016/j.jclepro.2012.11.0.

Xu, M., Weissburg, M., Newell, J.P., Crittenden, J.C., 2012. Developing a Science of Infrastructure Ecology for Sustainable Urban Systems. Environ. Sci. Technol. 2012, 46, 7928-7929. http://dx.doi.org/10.1021/es33025534.

Zuo, X.J., Fu, D.F., Li, H., Singh, R.P., 2011. Distribution Characteristics of Pollutants and Their Mutual Influence in Highway Runoff, Clean-Soil Air Water 39, 10, 956-963. . http://dx.doi.org/10.1002/clen.201000422. 